\title{
The Differential Reactions to Work Withdrawal Behaviours between Harassed Male and Female Employees
}

Jennifer M.I. Loh ${ }^{*}$ and Natasha Loi

School of Arts and Humanities, Edith Cowan University, 270 Joondalup Dr, Joondalup WA 6027, Australia

\begin{abstract}
Men and women reacted to workplace incivility differently. Female employees tended to experience and to put up more with workplace incivility than male employees. The current review examined the article, "Don't rock the boat: The moderating role of gender in the relationship between workplace incivility and work withdrawal," written by Loi, Loh \& Hine [1] that was published in the "Journal of Management Development." Using a quantitative survey of 317 adult employees working in various Australian companies, the researchers found that gender moderated the relationship between tolerance for workplace incivility and work withdrawal. Specifically, when female employees were exposed to increased workplace incivility tolerance, they decreased their work withdrawal practices. In contrast, as the levels of workplace incivility tolerance increased, men tended to increase their work withdrawal behaviours. However, this trend did not reach statistical significance.
\end{abstract}

\section{Publication History:}

Received: September 29, 2016

Accepted: May 16, 2017

Published: May 18, 2017

\section{Keywords:}

Behaviour, Psychological, Work withdrawal, Employees

\section{Background}

In the introduction of their journal article. The researchers first operationalised workplace incivility as, "low-intensity, disrespectful or rude deviant workplace behaviour with ambiguous intent to harm the target and is in violation of workplace norms for mutual respect" [2]. Next, they discussed the rise of incivility in the workplace, the subjective nature of workplace incivility (i.e., what is civil or uncivil depends on the interpretation of each individual), the ambiguous interpretation of "intent to harm" and the adverse consequences of workplace incivility. They included a number of negative organisational outcomes such as poor organisational productivity and poor services. They also discussed individual's physical and psychological outcomes including work withdrawal and stress.

Importantly, the researchers reported that a number of researchers in the past have posited that what was considered offensive or not varied along gender lines [3-5]. According to these past research, women were more sensitive than men to the nuances of social behaviours. Consequently women were more likely than men to notice and to experience workplace incivility. Additionally, men and women experienced the workplace differently. Women, for example tended to have less power than men in the workplace. According to Salin [6], these "perceived power imbalance is prerequisite for bullying to occur." Indeed, Pearson and Porath [7] have found that perpetrators of workplace incivility generally tended to be those with power (e.g. a manager) while the targets tended to be individuals with less power (e.g., a front desk secretary).

The researchers stated next that while research in this area has been insightful in helping us understand the experiences of workplace incivility between men and women, there is limited research on how this affects female versus male employee's willingness to complete work-related tasks (e.g., work withdrawal). There is also a dearth of research that looks at how men and women respond to organisations that tolerate workplace incivility. This is important when you consider that previous research has found that organisations that tolerated workplace incivility have high levels of employees' dissatisfaction [8], lost efficiency [9-10], high turnover (11-12], high absenteeism, and huge monetary losses [13]. Therefore, the aim of the reviewed article was to investigate whether gender would moderate the relationship between tolerance to workplace incivility and work withdrawal.

\section{Theoretical Argument of the Article}

The researchers drew upon power theory, social gender role theory, and selective incivility theory to explain the moderating role of gender in the relationship between workplace incivility and work withdrawal. From a social power perspective, power was measurable through the influence an individual has over other people or outcomes [14]. Society bestows power to a particular individual through social expectations and norms. For example, a manager would have more power than his secretary because a manager occupied a higher workplace hierarchy than the secretary. Power could also be segmented along gender roles. In many masculine societies, men were often regarded as authoritative figures while women were regarded as subordinates [15]. Perceived this way, gender itself became an organising principle for hierarchies and authorities. In their article, the researchers also offered a more recent theory to explain workplace incivility. Selective incivility theory posits that incivilities are evolved, old-fashioned discriminations that have become more subtle and ambiguous in nature given the political correctness of today's world [16]. In other words, incivility are forms of covert discriminations held by individuals who wanted to be perceived to be politically correct. These individuals only discriminated against people of colour or women when the discriminatory nature of their conduct was not evident [17]. As a result, many people misinterpreted these discriminations as rude or discourteous behaviours and not what they really were: racism and/or gender discrimination. Selective incivility theory is powerful because it provides an overarching, intersectional perspective based on "simultaneously consider[ing] the meaning and consequences of multiple categories of identity, difference, and disadvantage" [18] that can reflect the experiences of the less powerful as well as less privileged in our societies [19-20].

"Corresponding Author: Dr. Jennifer M.I. Loh, School of Arts and Humanities, Edith Cowan University, 270 Joondalup Dr, Joondalup WA 6027, Australia; E-mail: m.loh@ecu.edu.au

Citation: Loh JMI, Loi N (2017) The Differential Reactions to Work Withdrawal Behaviours between Harassed Male and Female Employees. Int J Psychol Behav Anal 3: 127. doi: https://doi.org/10.15344/2455-3867/2017/127

Copyright: @ 2017 Loh et al. This is an open-access article distributed under the terms of the Creative Commons Attribution License, which permits unrestricted use, distribution, and reproduction in any medium, provided the original author and source are credited. 
After the theoretical discussion, the researchers next examined how men and women handled conflict. Women, for instance were taught as children to be feminine, caring, and to master their anger [21-22]. In contrast, men were taught to legitimately defend their masculine identity [23-24] by adopting a "justice" moral orientation and to retaliate aggressively when under attack. This suggests that women would and should tolerate life hassles (e.g., workplace incivility) more than men. Drawing upon these evidences, the researchers hypothesised that gender would moderate the relationships between tolerance for workplace incivility and work withdrawal. Specifically, the impact of work withdrawal on workplace incivility would be stronger on men than on women.

To investigate their hypothesis, the researchers conducted hierarchical linear regression modelling using data collected from 317 participants $($ male $=102$ and female $=215)$. The average age for male participants was 41.83 years old $(S D=12.91)$ and for female participants, the average age was 37.33 years old $(S D=11.12)$. The average working week was 35.97 hours $(S D=10.80)$ and participants had been working on average with their current organisation for 7.89 years $(S D=7.39)$.

Results indicated that as levels of tolerance for incivility in the workplace increased, men tended to increase their work withdrawal behaviours. Although this trend did not reach statistical significance, the direction of the trend was in the predicted direction. Importantly, they found that when female employees were exposed to high levels of tolerance for workplace incivility, they significantly decreased their work withdrawal behaviours.

The researchers offered a number of explanations for their findings. For example, men tended to retaliate in an overt and direct manner (e.g. via confrontation or withdrawing from their work) whereas women tended to engage in covert retaliations such as gossiping. Similarly, men tended to confront their instigators more than women [25]. In contrast, when women encountered conflict, they tended to defend themselves by "silencing themselves" [25]. According to Wilson [26], "socialisation prepares women for their current roles, not for challenging those roles" which implies that women may have been socialised from an early age to know their "place" in society and to learn to "put up" with life injustices. Consequently, women might be more inclined to tolerate workplace incivility and to react less negatively to workplace incivility. This may partly explain why women in the researchers' study actually decreased their work withdrawal behaviours. Another explanation may be the need for women to maintain their job security. The researchers cited data from the Australian Bureau of Statistics (ABS) that while many women wanted more paid job, there were more men than women who were employed in full time employment [27]. Consequently, the need for financial security might have prevented many women from withdrawing from their work as they "put up" with workplace incivility.

\section{Study limitations Implications and Future Direction}

The researchers acknowledged a number of limitations in their study. The first issue they raised was the lack of representativeness of their predominantly white-collar, white Australian sample. The employment status (e.g., full-time, part-time or casual) of participants, the small unequal sample size between male and female workers (female, $\mathrm{N}=215$; male, $\mathrm{N}=102$ ), the age of participants (only recruited employees over the age of 18) were issues suggested by the researchers for future research considerations. Another issue raised by the researchers was the lack of power differentiation between perpetrators and targets. This is important because targets may respond to male versus female supervisors differently. To help address this question, the researchers have embarked on a second project that will attempt to collect data from three culturally diverse countries. As part of this second project, the researchers will specifically set out to identify the instigators, the targets and the job status of each participant. For example, male manager, female manager, male colleague, female colleague, male subordinate or female subordinate. Participants will also be asked to report how often they instigated (i.e., perpetrator) or experienced (i.e., targets) workplace incivility from their supervisors, colleagues and subordinates. This will help identify the influence of power differential between instigators and targets. Despite these limitations, the researchers believed that their present study has added to the work in the workplace incivility, diversity, genders and equity research area. They also stated that the findings from their study would provide useful information needed by managers and organisations to more effectively manage conflict in the workplace.

\section{Competing Interests}

The authors declare that they have no competing interests.

\section{References}

1. Loi NM, Loh JMI, Hine DW (2015) Don't rock the boat: The moderating role of gender in the relationship between workplace incivility and work withdrawal. J Management Development 34: 169-186.

2. Andersson LM, Pearson CM (1999) Tit for tat? The spiraling effect of incivility in the workplace. The Acad of Management Rev 24: 452-471.

3. Berdahl JL, Moore C (2006) Workplace harassment: Double-jeopardy for minority women. J Applied Psychol 91: 426-436.

4. Konrad AM, Gutek BA (1986) Impact of work experiences on attitudes toward sexual harassment. Admin Science Quart 31: 422-438.

5. Montgomery K, Kane K, Vance CM (2004) Accounting for differences in norms of respect: A study of assessments of incivility through the lenses of race and gender. Group \& Org Management 29: 248-268.

6. Salin D (2003) Ways of explaining workplace bullying: A review of enabling, motivating and precipitating structures and processes in the work environment. Human Relations 56: 1213-1232.

7. Pearson CM, Porath CL (2005) On the nature, consequences, and remedies of workplace incivility: No time for 'nice'? Think again". Acad of Management Executive 19: 7-18.

8. Estes B, Wang J (2008) Workplace incivility: Impacts on individual and organization Performance. Human Resource Develop Rev 7: 218-240.

9. Gonthier G (2002) Rude Awakenings: Overcoming the Civility Crisis in the Workplace (1st edition), Chicago: IL Dearborn Trade, USA, 256 p.

10. Pearson CM, Andersson LM, Porath CL (2000) Assessing and attacking workplace incivility. Organizational Dynamics 29: 123-137.

11. Kane K, Montgomery K (1998) A framework for understanding disempowerment in organizations. Human Resources Management 37 263-275.

12. Tepper BJ (2000) Consequences of abusive supervision. Acad Management J 43: 176-190.

13. Cortina L, Magley V (2009) Patterns and profiles of response to incivility in the workplace. J Occup Health Psycho 14: 272-288.

14. French JRP Jr, Raven BH (1959) The Bases of Social Power. In Cartwright D (Ed) Studies in Social Power, Ann Arbor, MI, Institute for Social Research, University of Michigan, USA, pp. 150-167.

15. Rudman LA, Kilianski SE (2000) Implicit and explicit attitudes toward female authority. Pers Soc Psychol Bulletin 26: 1315-1328.

16. Kabat-Farr D, Cortina LM (2012) Selective Incivility: Gender, Race, and the Discriminatory Workplace. In Fox S, Lituchy T. (Eds) Gender and the Dysfunctional Workplace, Edward Elgar Publishing, Northhampton, MA, pp. 107-119.

17. Cortina LM (2008) Unseen justice: Incivility as modern discrimination in organizations. Acad of Management Rev 33: 55-75. 
Citation: Loh JMI, Loi N (2017) The Differential Reactions to Work Withdrawal Behaviours between Harassed Male and Female Employees. Int J Psychol Behav Anal 3: 127. doi: https://doi.org/10.15344/2455-3867/2017/127

Page 3 of 3

18. Cole ER (2009) Intersectionality and research in psychology. Am Psychologist 64: 170-180.

19. Browne I, Misra J (2003) The intersection of gender and race in the labor market. Annual Rev of Soc 29: 487-513.

20. Greenman E, Xie Y (2008) Double jeopardy? The interaction of gender and race on earnings in the United States. Social Forces 86: 1217-1244.

21. Maltz DN, Borker RA (1982) A Cultural Approach to Male-Female Miscommunication. In Gumperz JJ (Ed) Language and Social Identity, New York: NY, Cambridge University Press, USA, pp. 196-216.

22. Rothleder D (1992) Disappearing. Phil Today 36: 173-180.

23. Felson RB (1982) Impression management and the escalation of aggression and violence. Soc Psychol Quart 45: 245-254.

24. Frodi A, Macaulay J, Thome PR (1977) Are women always less aggressive than men? A review of the experimental literature. Psychol Bulletin 84: 634660 .

25. Belenky MF, Clinchy BM, Goldberger, NR, Tarule, JM (1986) Women's Way of Knowing: the Development of Self, Voice and Mind. (1st editions), New York: New York Basic Books, USA, 288 p.

26. Wilson FM (2003) Organizational Behaviour and Gender (2nd edition) Aldershot: Hants, Ashgate Publishing Limited, England, 260 p.

27. Australian Bureau of Statistics (ABS) (2012) Gender indicators, Australia No. 4125 . 